\title{
Across-scale patterning of plant-soil-water interactions surrounding tree islands in Southern Everglades landscapes
}

\author{
Erin J. Hanan · Michael S. Ross
}

Received: 9 June 2008/Accepted: 6 November 2009/Published online: 29 November 2009

(C) Springer Science+Business Media B.V. 2009

\begin{abstract}
The freshwater Everglades is a complex system containing thousands of tree islands embedded within a marsh-grassland matrix. The tree islandmarsh mosaic is shaped and maintained by hydrologic, edaphic and biological mechanisms that interact across multiple scales. Preserving tree islands requires a more integrated understanding of how scale-dependent phenomena interact in the larger freshwater system. The hierarchical patch dynamics paradigm provides a conceptual framework for exploring multiscale interactions within complex systems. We used a three-tiered approach to examine the spatial variability and patterning of nutrients in relation to site parameters within and between two hydrologically defined Everglades landscapes: the freshwater Marl Prairie and the Ridge and Slough. Results were scaledependent and complexly interrelated. Total carbon and nitrogen patterning were correlated with organic matter accumulation, driven by hydrologic conditions at the system scale. Total and bioavailable phosphorus were most strongly related to woody plant patterning within landscapes, and were found to be 3 to 11 times more concentrated in tree island soils compared to surrounding marshes. Below canopy resource islands in the slough were elongated in a downstream
\end{abstract}

E. J. Hanan $(\bowtie) \cdot$ M. S. Ross

Florida International University, University Park, Building OE, Room: 14811200 SW 8th St, Miami, FL 33199, USA

e-mail: erin.hanan@fiu.edu direction, indicating soil resource directional drift. Combined multi-scale results suggest that hydrology plays a significant role in landscape patterning and also the development and maintenance of tree islands. Once developed, tree islands appear to exert influence over the spatial distribution of nutrients, which can reciprocally affect other ecological processes.

Keywords Hierarchical patch dynamics paradigm . Hierarchy theory - Soil heterogeneity .

Resource islands · Peat accumulation ·

Phosphorus redistribution - Ridge and Slough .

Freshwater marl prairies · Florida wetlands .

Hydrologic management

\section{Introduction}

Spatial heterogeneity is pervasive across all scales within the freshwater Everglades system. The complex relationship between spatial patterning and tightly coupled ecological and biogeochemical processes presents a significant challenge to our understanding and preservation of the system's component parts. The Hierarchical Patch Dynamics Paradigm (HPDP) provides a framework for exploring multiscale patterns and processes by explaining how scaledependent phenomena relate to one another in heterogeneous systems (Wu and Loucks 1995). 
HPDP might be particularly useful in structuring data that describe the spatial variability and patterning of nutrients in relation to cross-scale site parameters in the Everglades. Focused interpretations of such data are essential in determining how ecosystems function (Vitousek and Sanford 1986), estimating the rates of ecological processes (Miller et al. 2004) and predicting the effects of management on nutrient patterns (McGrath et al. 2001).

HPDP integrates hierarchy theory with Watt's patch dynamics paradigm in order to emphasize the multi-scaled nature of ecosystem pattern and process dynamics (Watt 1947; Wu and Loucks 1995; Wu 1999). The two major principles inherent to HPDP are (1) landscapes are fundamentally complex, containing multiple nested subsystems, and are themselves nested components of larger systems, and (2) landscapes are spatially heterogeneous and dynamic, resulting from interactions with variables that exist at equivalent hierarchical tiers (i.e. holons). Levels in a hierarchy materialize from the unique set of processes that govern each spatial scale. Patches at higher levels impose constraints on lower-level processes, while interactions between lower-level patches provide the initiating conditions for the emergence of higher-level systems (Gillson 2004). Interactions between several biogeochemical and environmental processes maintain heterogeneous and dynamic vegetation assemblages within the freshwater Everglades system, making it well suited for hierarchical analysis.

Within Everglades landscapes, hydrology, soil and vegetation pattern, connected through an intricate network of feedback loops, give rise to tree islands juxtaposed against lower elevation sloughs and mixed prairies. Once established in the marsh, woody plants are believed to generate below-canopy resource islands through autogenic nutrient and peat redistribution mechanisms (Burke et al. 1998; Wetzel et al. 2005). Rietkerk et al. (2004) described one such mechanism occurring in temperate peatlands, where mass flow of groundwater nutrients, especially nitrogen $(\mathrm{N})$, move towards areas with higher vascular plant biomass due to differential transpiration rates. Diffusion is a related process particularly important for phosphorus $(\mathrm{P})$ that creates local nutrient concentration gradients when uptake exceeds mass flow supply (Casper and Jackson 1997; Kadlec 1999). Osmotically drawn nutrients stored within woody plant tissues are eventually deposited as peat, thus fortifying local resource pools and raising surface elevations. As resource islands develop, resident communities become increasingly resistant to environmental stressors such as flooding and fire (Schlesinger et al. 1996). At a larger scale, hydrologic variation among Everglades landscapes can affect the size, shape and elongation of component resource patches. Hydrology is said to be the underlying driver of landscape organization in the Everglades (Gunderson 1994; White 1994), through its direct impacts on vegetation dynamics and on edaphic patterns and processes, including nutrient redistribution.

The effects of hydrologic compartmentalization evident within Everglades communities are often magnified upwards through myriad nested ecological scales. For example, hydrologic changes over the past 60 years have greatly reduced both the size and number of tree islands, particularly within the Water Conservation Areas (WCAs; Patterson and Finck 1999; Hofmockel et al. 2008; Wetzel et al. 2009), resulting in a significant decline in overall landscape complexity (Sklar et al. 2004). Drainage-induced woody plant expansion also alters the scale of soil and vegetation heterogeneity within the Everglades Marl Prairie landscape. A more integrative understanding of the scale-dependent interactions between hydrology, soil parameters and vegetation patterning is necessary to restore the complex Everglades system in the wake of recent human-induced changes.

Effective multi-scale analysis in complex systems such as the Everglades requires a focus on properly scaled sub-units that are large enough to incorporate interrelated processes, and small enough to minimize information loss. Farina (2006), suggests the use of nested scales that represent distinct grains of resolution. Previous studies have characterized nutrient dynamics within Everglades communities and/or landscapes (e.g. Orem et al. 2002; Jayachandran et al. 2004; Ross et al. 2006; Wetzel et al. 2009), but few have employed a multi-scale approach. In this study we aimed to analyze the spatial variability and patterning of nutrients in relation to cross-scale site parameters within and among two hydrologically defined Everglades landscapes; the freshwater Marl Prairie and the Ridge and Slough. Specifically, we (1) quantified the patterning of soil properties and environmental variables within and surrounding tree islands, (2) revealed whether those patterns varied 
systematically between landscapes, and (3) identified the spatial orientation of resource patches, identifying whether they were aligned with hydrologic flow. We interpreted our results within the context of the Hierarchical Patch Dynamics Paradigm with the hope of providing new insight into Everglades conservation and restoration efforts.

\section{Methods}

\section{Study site}

Our focal region extended eastward from Shark Slough to the seasonally flooded mixed marl prairies of Everglades National Park (ENP). The Ridge and Slough and Marl Prairie landscapes are dotted with tree islands of various sizes and types. Field sampling took place between January and April of 2006 at tree island-centered sites distributed across the two landscapes (Fig. 1).

Marl prairies are characterized by calcitic marl soil, a thick cover of calcareous periphyton, and a rocky limestone substratum with micro-topographic features including outcroppings and solution holes. Marls are usually classified as Fluvaquents, accumulating from the microbial and chemical precipitation of calcium carbonate $\left(\mathrm{CaCO}_{3}\right)$ (Harris and Hurt 1999). Prairies are inundated approximately 3-7 months per year, and exhibit high plant diversity. They are exceptionally oligotrophic, with several factors contributing to their extreme P-limitation, the most significant being P-immobilization by periphyton (Noe et al. 2001).

The Ridge and Slough landscape bisecting ENP is comprised primarily of wide, low elevation sloughs containing emergent or floating aquatic species, subdivided by alternating elongated sawgrass ( $\mathrm{Cla}$ dium jamaicense) ridges and tree islands that are decimeters higher in elevation. Landscape features within the Ridge and Slough peatlands are arranged parallel to the predominant historical direction of hydrologic flow (Ross et al. 2006). Lower slough communities have relatively long hydroperiods, inundated approximately 11 months per year, and are therefore the main conduits for water flow through the Everglades. Ridge and Slough soils are classified as Histosols due to the accumulation of peat under nearly continuous submergence, which prevents the oxidation of organic matter (Kushlan 1990). Soils in Ridge and Slough marshes are also extremely oligotrophic, and soil nutrients tend to remain organically bound.

Many Everglades tree islands form on areas of slight topographic relief where flooding stress that would otherwise prevent woody growth is ameliorated (Loveless 1959). Everglades tree islands range from $10 \mathrm{~m}^{2}$ to over $700,000 \mathrm{~m}^{2}$ in size; the largest located in Shark Slough (Wetzel et al. 2005). There
Fig. 1 Location of Everglades National Park covering 610,497 hectares along the Southern tip of Florida, USA. Study sites 1 , 2, 5 and 6 are in the freshwater Marl Prairie and $3,4,7$ and 8 are in the Ridge and Slough.

Sampling design at each site is shown in the lower right corner. Rings T1-2 are in tree islands, TM1-3 are in transitional marshes, OM12 are in outer marshes. Map was created using ESRI ArcMap 9.3

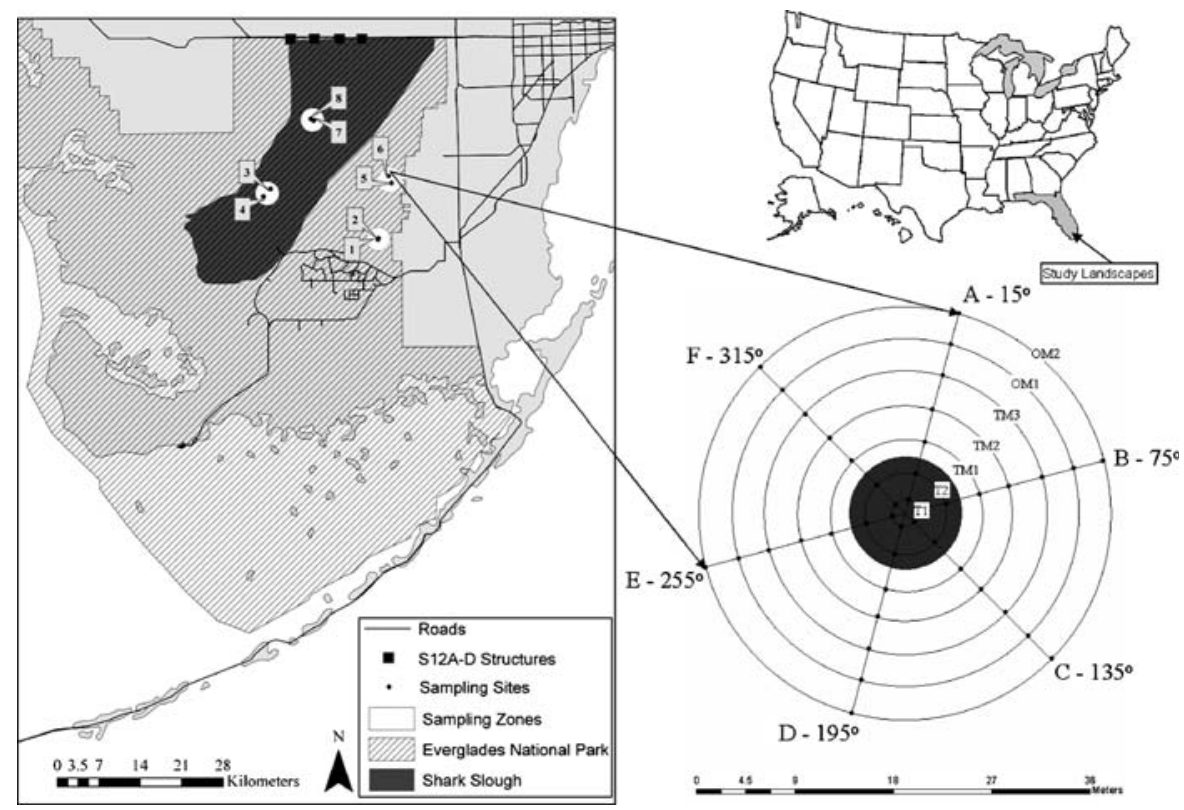


are two distinct categories of tree islands found in the Everglades: those composed entirely of wetland species (e.g. Salix caroliniana), and those containing both wetland and upland species (e.g. Bursera simaruba). Tree islands with significant upland portions exist only in the northern Everglades and Shark River Slough. They are frequently teardrop shaped and aligned with their rounded ends facing upstream in a general northward direction and their southern ends tapering off in the direction of water flow. In terms of total density and area, purely wetland tree islands are the most abundant across the Everglades freshwater system. Total soil phosphorus is typically between 6 and 100 times more concentrated in tree islands than in surrounding marshes (Jayachandran et al. 2004). Also, decomposition rates are generally higher within their more oxidized soils, resulting in increased nutrient availability for woody growth (Baker et al. 2001).

Hydroperiods in the Everglades are co-influenced by climatic drivers and operations of the South Florida Water Management District (SFWMD), which controls more than $2,500 \mathrm{~km}$ of canals and levees in addition to hundreds of water control structures. Surface flow to ENP is primarily channeled through the S-12A-D structures located along the park's northern border (Fig. 1). The South Florida wet season lasts for roughly 5 months from May through the beginning of October, followed by drier conditions during the remainder of the year. Regional mean annual precipitation ranges from 120 to $160 \mathrm{~cm}$, and mean daily temperatures range from 17 to $25^{\circ} \mathrm{C}$.

\section{Sampling}

In this study we employed a three-tiered, hierarchically nested sampling approach. Everglades landscapes comprised our focal level, and patterns and processes were also evaluated at the local level (i.e. component tree island-marsh patches) and at the system level (i.e. the freshwater Everglades). Eight tree island-centered sampling sites were randomly selected from the northern and southern regions of the Marl Prairie and Shark Slough (Fig. 1). Northern and southern sampling zones (4 km diameter) were delineated in each landscape type, and two small tree islands between 12 and $20 \mathrm{~m}$ in diameter were identified in each of the four zones after aerial reconnaissance.

A series of six line segments $(\mathrm{A}-\mathrm{F})$ radiating from the center of each tree island at $60^{\circ}$ intervals (Fig. 1) were created, each containing seven sampling points equally spaced $3 \mathrm{~m}$ apart. The first sampling point on each line segment was placed within the tree island $4.5 \mathrm{~m}$ from its edge. Edges were defined as the outermost portion of tree canopy closure. This arrangement resulted in seven irregularly shaped sampling rings (T1, T2, TM1, TM2, TM3, OM1 and OM2) that radiated from the center of each tree island and crossed 3 communities (Tree island, Transitional Marsh and Outer Marsh). Elevations (based on autolevel surveys from benchmarks of known elevation), soil and water depths, dominant vegetation and canopy height were determined at each of the 42 sampling points per site. Elevation surfaces were created via ordinary kriging using Surfer 8 (Golden Software, Inc.). Tree island compositions were determined based on visual estimates of canopy cover. Hydroperiods were calculated using elevation measurements, coupled with 6 year (2000-2006) Everglades Depth Estimation Network stage record data (EDEN 2008). Soil cores were extracted from 0 to $20 \mathrm{~cm}$ depth or to bedrock (whichever was reached first) at each sampling point. Sites were revisited in December, 2006 to collect additional samples from a 6-point subset for $\mathrm{pH}$, and inorganic nutrient analyses. These subsamples were collected from the innermost and outermost rings ( $\mathrm{T} 1$ and $\mathrm{OM} 2$ ) on line segments A, C and D at each site (Fig. 1).

All samples were brought to the laboratory immediately for analysis. Samples were homogenized and large materials (i.e. roots, shells, leaves, etc.) were removed using calipers. A portion of each soil sample was air-dried, ground and run through a $1 \mathrm{~mm}$ sieve.

Laboratory bulk density and soil water content were determined concurrently using a modified version of the Lynn et al. (1974) procedure. Soil $\mathrm{pH}$ was attained for $10 \mathrm{~g}$ wet soil subsamples combined with distilled deionized water $\left(\mathrm{DDIH}_{2} \mathrm{O}\right)$ in $1: 1$ ratio slurries, and recorded using a calibrated standard combination $\mathrm{pH}$ electrode (Jones 2001). Organic matter $(\mathrm{OM})$ and carbonate $\left(\mathrm{CO}_{3}\right)$ contents were determined by Loss on Ignition (LOI; Dean 1974). Total carbon (TC) and total nitrogen (TN) concentrations were determined using a Perkin Elmer 
2400 CHNS Analyzer. Total phosphorus (TP) samples were digested using a soil-adapted version of the ashing-acid hydrolysis method outlined by Solorzano and Sharp (1980), and the resulting soluble reactive phosphorus (SRP) was analyzed colorimetrically according to the EPA standard method (365.1) for orthophosphate P (O'Dell 1993). Exchangeable (potassium chloride extractable) nitrate and ammonium concentrations $\left(\mathrm{KCl}-\mathrm{NO}_{3}, \mathrm{KCl}-\mathrm{NH}_{4}\right)$ were determined for subsamples to provide an indication of biologically available $\mathrm{N}$ forms. Extraction methods were based on those outlined by Forester (1995), and samples were analyzed colorimetrically with a matched matrix solution (Mulvaney 1996). Exchangeable (sodium bicarbonate extractable) phosphate concentrations $\left(\mathrm{NaHCO}_{3}-\mathrm{PO}_{4}\right)$ were also determined for subsamples as an indication of biologically available P forms. Samples were extracted based on a modification of the Olsen et al. (1954) procedure and analyzed colorimetrically. All results were normalized to $\mu \mathrm{g} / \mathrm{g}$ dry weight concentrations.

\section{Statistical analyses}

Spatial variations in soil properties were analyzed using three-way nested factorial (mixed model) analyses of variance (ANOVA). Landscape and Sampling Ring were considered fixed factors, while Site nested within Landscape was considered random. ANOVAs were run using SPSS version 14.0 for both gravimetrically and volumetrically expressed data. Orthogonal contrasts were applied to hydroperiod, elevation, bulk density, water content, OM, carbonate, TC, TN and TP measurements in order to compare (1) tree island (i.e. T1 and T2) and outer marsh (i.e. OM1 and OM2) communities within each landscape, (2) tree island communities among landscapes, and (3) outer marsh communities among landscapes. Slightly modified contrasts were applied to $\mathrm{pH}$ and bioavailable nutrient subsamples in order to compare (1) tree island (i.e. T1) and outer marsh (i.e. OM2) communities within each landscape, and (2) the marl prairie vs. slough landscape. Where necessary, data were $\log _{10}$ transformed to achieve approximate homoscedasticity at the $\alpha=0.10$ level.

Orthogonal contrasts were also used to test for variation between upstream and downstream TP concentrations. Differences between tree island (T1-T2) and marsh (OM1-OM2) TP concentrations were calculated for each line segment $(\mathrm{A}-\mathrm{F})$ in each landscape. It was assumed that if resource islands were elongated in the downstream direction, intercommunity differences would be larger for upstream than downstream line segments. The directional orientations of landscape features near each study site were used as surrogates for flow direction. For instance, at Chekika (a hammock close to sites 1, 2, 5 and 6), more than $95 \%$ of landscape features are oriented between 135 and $255^{\circ}$ (Ruiz and Ross 2004). At hydrostations P36 (adjacent to sites 7 and 8) and NP203 (adjacent to sites 3 and 4), a similar proportion of landscape features are oriented between 195 and $255^{\circ}$. Therefore, differences along line segments F, A and B (upstream) were contrasted with those along segments C, D and E (downstream) in the Marl Prairies, while differences along line segments $\mathrm{A}$ and B (upstream) were contrasted with those along segments $\mathrm{E}$ and $\mathrm{F}$ (downstream) in the Ridge and Slough.

Non-metric multidimensional scaling (NMDS; using PC-ORD and the Mather (1976) algorithm) was performed on a Sorensen (Bray and Curtis 1957) dissimilarity matrix to visualize the variation in tree island species assemblages across the study region. Cover data were relativized by species and arcsine square root transformed. Weighted-average scores were used to plot individual species dissimilarities as they related to the NMDS site ordination.

\section{Results}

Environmental variables

Hydroperiods were consistently shorter in tree islands than in outer marshes, and were also shorter in the Marl Prairie than in the Ridge and Slough landscape (Table 1). Hydroperiod is strongly dependent on bedrock and surface elevations, which were both higher in prairie tree islands than in outer marshes. Slough tree islands had higher surface elevations than outer marshes. Although bedrock elevations were much higher in the prairie than in the slough, soil depth was much greater in the slough, thus dampening extreme elevation differences. Nevertheless, slough surface elevations were lower than those in the prairie across community types (Table 1 ). Lower elevations and deeper soils in the Ridge and Slough 
Table 1 Mean parameter values, element concentrations and contrast $P$-values within and among landscapes

\begin{tabular}{|c|c|c|c|c|c|c|c|c|}
\hline \multirow[t]{2}{*}{ Parameter $^{\mathrm{a}, \mathrm{b}}$} & \multicolumn{3}{|l|}{ Prairie } & \multicolumn{3}{|l|}{ Slough } & \multicolumn{2}{|c|}{ Prairie vs. Slough } \\
\hline & $\begin{array}{l}\text { Tree } \\
\text { island }\end{array}$ & $\begin{array}{l}\text { Outer } \\
\text { marsh }\end{array}$ & Contrast & $\begin{array}{l}\text { Tree } \\
\text { island }\end{array}$ & $\begin{array}{l}\text { Outer } \\
\text { marsh }\end{array}$ & Contrast & $\begin{array}{l}\text { Tree } \\
\text { islands }\end{array}$ & $\begin{array}{l}\text { Outer } \\
\text { marshes }\end{array}$ \\
\hline Hydroperiod (days $\cdot$ year $^{-1}$ ) & 97.3 & 184.1 & $P<0.001$ & 233.1 & 343.0 & $P<0.001$ & $P<0.001$ & $P<0.001$ \\
\hline Bedrock elevation (mamsl; NAVD88) & 1.190 & 0.975 & $P=0.056$ & 0.179 & 0.138 & $P=0.788$ & $P<0.001$ & $P<0.001$ \\
\hline Surface elevation (mamsl; NAVD88) & 1.350 & 1.158 & $P=0.037$ & 1.072 & 0.802 & $P=0.001$ & $P=0.086$ & $P<0.001$ \\
\hline Bulk density $\left(\mathrm{g} \cdot \mathrm{cm}^{-3}\right)$ & 0.274 & 0.476 & $P<0.001$ & 0.125 & 0.122 & $P=0.912$ & $P<0.001$ & $P<0.001$ \\
\hline Fractional water content $\left(\mathrm{g} \cdot \mathrm{cm}^{-3}\right)$ & 0.625 & 0.549 & $P<0.001$ & 0.867 & 0.873 & $P=0.755$ & $P<0.001$ & $P<0.001$ \\
\hline $\mathrm{OM}\left(\mathrm{mg} \cdot \mathrm{g}^{-1}\right)$ & 445.3 & 193.9 & $P<0.001$ & 857.7 & 818.9 & $P=0.430$ & $P<0.001$ & $P<0.001$ \\
\hline Carbonate $\left(\mathrm{mg} \cdot \mathrm{g}^{-1}\right)$ & 175.0 & 382.4 & $P<0.001$ & 27.7 & 28.5 & $P=0.985$ & $P=0.001$ & $P<0.001$ \\
\hline $\mathrm{TC}\left(\mathrm{mg} \cdot \mathrm{g}^{-1}\right)$ & 259.1 & 141.7 & $P<0.001$ & 444.1 & 449.7 & $P=0.765$ & $P<0.001$ & $P<0.001$ \\
\hline $\mathrm{TN}\left(\mathrm{mg} \cdot \mathrm{g}^{-1}\right)$ & 17.1 & 7.4 & $P<0.001$ & 28.7 & 30.9 & $P=0.183$ & $P<0.001$ & $P<0.001$ \\
\hline $\mathrm{TP}\left(\mu \mathrm{g} \cdot \mathrm{g}^{-1}\right)$ & 979.3 & 184.6 & $P<0.001$ & 1240.5 & 274.3 & $P<0.001$ & $P=0.768$ & $P=0.049$ \\
\hline $\mathrm{pH}$ & 7.417 & 7.623 & $P=0.486$ & 6.436 & 6.367 & $P=0.815$ & $P<0.001$ & \\
\hline $\mathrm{NO}_{3}-\mathrm{N}\left(\mu \mathrm{g} \cdot \mathrm{g}^{-1}\right)$ & 18.3 & 12.3 & $P=0.447$ & 3.8 & 3.5 & $P=0.968$ & $P=0.043$ & \\
\hline $\mathrm{NH}^{4}-\mathrm{N}\left(\mu \mathrm{g} \cdot \mathrm{g}^{-1}\right)$ & 5.6 & 3.3 & $P=0.738$ & 16.8 & 14.5 & $P=0.748$ & $P=0.028^{\mathrm{c}}$ & \\
\hline $\mathrm{PO}_{4}-\mathrm{P}\left(\mu \mathrm{g} \cdot \mathrm{g}^{-1}\right)$ & 12.8 & 2.2 & $P=0.005$ & 27.1 & 6.2 & $P=0.109$ & $P=0.018^{\mathrm{c}}$ & \\
\hline
\end{tabular}

were associated with taller tree island canopies (Fig. 2a, b).

Bulk densities were lower within prairie tree islands than in outer marshes (Table 1). Prairie tree island and outer marsh samples both had higher bulk densities than samples from slough tree islands and outer marshes, respectively. Fractional water content, which affects soil chemistry and nutrient transport, was higher in tree island than in marsh soils in the prairie environment. In the slough, water content exhibited little local variation, and was much higher than in the prairie (Table 1). $\mathrm{pH}$ values were lower within the slough than the prairie, but local variability was not significant in either landscape (Table 1).

Patterning of nutrients and carbon forms

The highly variable bulk densities noted in Table 1 complicate interpretation of relationships between nutrient parameters and vegetation patterning, because measured values change depending on whether they are expressed gravimetrically or volumetrically. In some situations, volumetric data may be more meaningful than gravimetric data, since assumptions regarding the relationship between resources and vegetation patterning should relate to soils in their natural state (Mehlich 1972). However, volumetric data are also imperfect since they do not take into account soil structure, microbial dynamics and/or the relative ability of soil types to retain and release nutrients. With this in mind, ANOVAs were run on both gravimetric and volumetric nutrient data. In most cases results from the two data sets were similar, however discrepancies between them occurred for two response variables: $\log _{10} \mathrm{PO}_{4}-\mathrm{P}$ and $\mathrm{NH}_{4}-\mathrm{N}$. Because volumetrically based measurements include greater error, particularly within Everglades waterlogged soils, our tables and figures present gravimetric data. However, our discussion emphasizes results that were significant for both means of expression.

$\mathrm{OM}$, TC and TN varied significantly between levels of the Landscape by Ring interaction (ANOVA $P<0.001$ for all three variables), and were all more concentrated in Marl Prairie tree islands than outer 
Fig. 2 a Bedrock, surface and vegetation elevations in Marl Prairie sites 1, 2, 5 and 6. b Bedrock, surface and vegetation elevations in Ridge and Slough sites 3, 4, 7 and 8
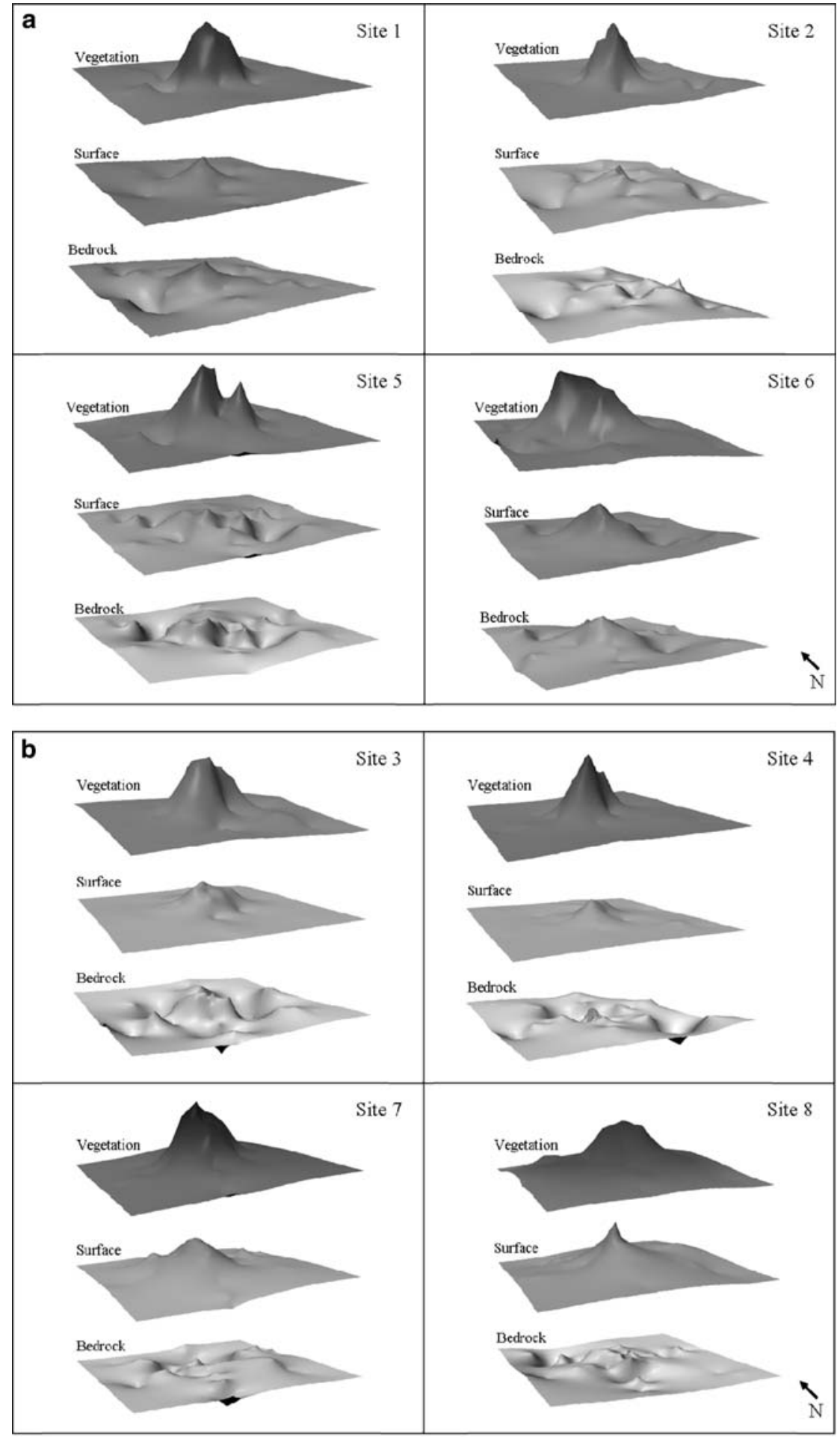

$\begin{array}{lllllllllllllll}0 & 0.5 & 1 & 1.5 & 2 & 2.5 & 3 & 3.5 & 4 & 4.5 & 5 & 5.5 & 6 & 6.5 & 7\end{array}$ 
marshes (Table 1). Also, OM, TC and TN concentrations were lower in Marl Prairie than in Ridge and Slough landscapes. Within and across-landscape patterns in carbonate content varied inversely to those of OM, TC and TN, with highest concentrations in Marl Prairie landscapes, especially in the marsh environment (Table 1).

$\log _{10} \mathrm{TP}$ varied significantly between sampling rings (ANOVA $P<0.001$ ), and was far more concentrated in both prairie and slough tree islands than in outer marshes (Table 1). Slough outer marshes had higher $\log _{10} \mathrm{TP}$ concentrations than prairie outer marshes.

$\mathrm{KCl}$ extractable $\mathrm{NO}_{3}-\mathrm{N}$ and $\mathrm{NH}_{4}-\mathrm{N}$ made up a very small gravimetric proportion of $\mathrm{TN}$ across both communities and landscapes (Fig. 3a). $\mathrm{NO}_{3}-\mathrm{N}$ was more concentrated within the prairie landscape than within the slough (ANOVA $P=0.003$ ), whereas $\mathrm{NH}_{4}-\mathrm{N}$ was more concentrated within the slough than within the prairie (ANOVA $P=0.037$; Fig. 3a). However $\mathrm{NH}_{4}-\mathrm{N}$ variation between landscapes was only significant for gravimetric data (volumetric ANOVA $P=0.746$ ). No significant differences in $\mathrm{NH}_{4}-\mathrm{N}$ concentrations were found between communities within the two landscapes (Table 1).

As with inorganic $\mathrm{N}, \log _{10}$ transformed $\mathrm{NaHCO}_{3}$ extractable $\mathrm{PO}_{4}-\mathrm{P}$ was a minor gravimetric component of TP across both communities and landscapes (Fig. 3b). $\log _{10} \mathrm{PO}_{4}-\mathrm{P}$ varied significantly between sampling rings (ANOVA $P<0.001$ ), and was significantly higher within prairie tree islands than in outer marshes. Also, $\log _{10} \mathrm{PO}_{4}-\mathrm{P}$ was moderately higher in slough tree islands than in outer marshes (Table 1). Samples collected from the slough had higher $\log _{10} \mathrm{PO}_{4}-\mathrm{P}$ concentrations than samples collected from the prairie (ANOVA $P=0.011$ ), though only for gravimetric data (volumetric ANOVA $P=0.356$ ).

Orthogonal contrasts confirmed that the dissimilarity between tree island and marsh $\log _{10} \mathrm{TP}$ concentrations were higher along upstream vs. downstream sampling segments in the slough $(P=0.015)$, while no similar spatial pattern was found within the prairie.

Tree island woody species cover varied among landscapes (Table 2). The NMDS species ordination (carried out in 50 runs) exhibited an exceptionally low stress level of 0.002 using Kruskal's (1964) metric. Results were ideally expressed using two
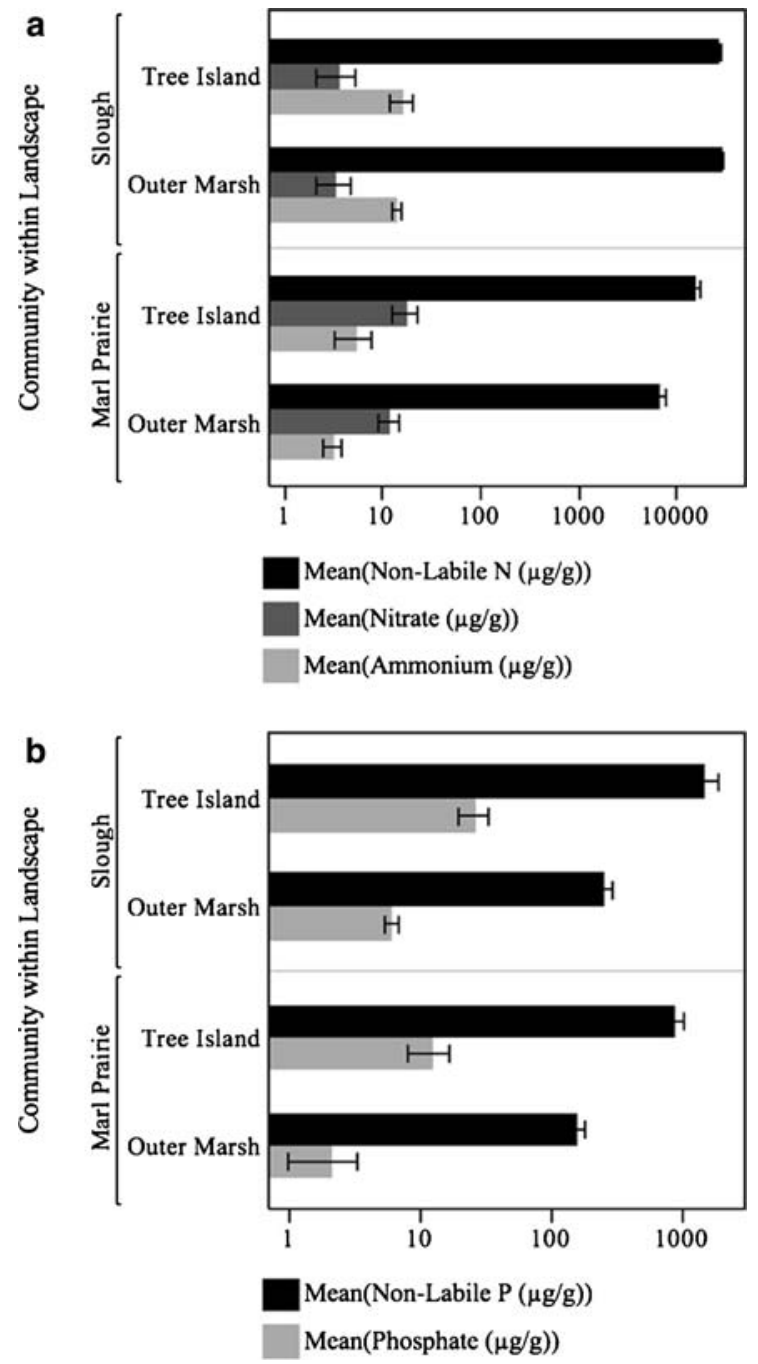

Fig. 3 a Mean nitrogen forms on a logarithmic scale. Bars show one standard error from the mean. b Mean phosphorus forms on a logarithmic scale. Bars show standard error

dimensions, with $22 \%$ of variance attributable to axis 1 and $53.9 \%$ of variance attributable to axis 2 . Monte Carlo results revealed that in 249 runs there was only a $1.2 \%$ likelihood of randomized data producing a stress level at or below 0.002 using 2 axes. The NMDS ordination plot revealed that sampling sites within the Marl Prairie and Ridge and Slough exhibited considerable compositional association within landscapes (Fig. 4), though two sites (Site 4, slough; and Site 5, prairie) formed a mixed landscape group. 
Table 2 Species cover estimated at various canopy layers and mean canopy heights for each tree island nested within the Marl Prairie and Ridge and Slough landscapes

\begin{tabular}{|c|c|c|c|c|c|c|c|c|}
\hline \multirow[t]{2}{*}{ Species } & \multicolumn{4}{|c|}{ Prairie } & \multicolumn{4}{|c|}{ Slough } \\
\hline & 1 & 2 & 5 & 6 & 3 & 4 & 7 & 8 \\
\hline Annona glabra & & & & & 5 & & 1 & 2 \\
\hline Chrysobalanus icaco & & & & & 5 & & 4 & 5 \\
\hline Cocaloba diversifolia & & 2 & & & & & & \\
\hline Ficus auria & & 1 & 1 & & & 1 & & \\
\hline Ilex cassine & & 2 & & & 2 & & & \\
\hline Magnolia virginiana & & & & & 2 & & & 4 \\
\hline Metopium toxiferum & & 1 & & & & & & \\
\hline Morella cerifera & 5 & 5 & 5 & 6 & 5 & 6 & 5 & 5 \\
\hline Myrsine floridensis & 4 & 5 & & 4 & & & & \\
\hline Persea borbonia & 3 & 1 & 2 & 2 & 3 & 3 & & \\
\hline Randia aculeata & 2 & & & & & & & \\
\hline Sabal palmetto & 4 & 3 & 1 & 6 & & & & \\
\hline Salix caroliniana & 2 & & 2 & & 1 & 1 & 2 & 3 \\
\hline Schinus terebinthifolius ${ }^{\mathrm{a}}$ & & & 5 & & & & & \\
\hline Sidroxylon reclinatum & & 1 & & & & & & \\
\hline Sidroxylon salicifolium & 2 & & & & & & & \\
\hline $\begin{array}{l}\text { Mean Canopy Height } \\
\text { (m) }\end{array}$ & 3.1 & 2.6 & 2.8 & 2.9 & 3.1 & 3.2 & 3.6 & 3.4 \\
\hline
\end{tabular}

Cover classes: $1=0-1 \%, 2=1-4 \%, 3=4-16 \%, 4=16-$ $33 \%, 5=33-66 \%$, and $6>66 \%$

a Invasive exotic

\section{Discussion}

Our results support the premise that Everglades ecosystems are hierarchically structured, with unique patterns and processes governing each level of biogeochemical organization (Fig. 5). Clearly hydrology plays a significant role in landscape patterning and the development of tree islands. Once developed, tree islands appear to exert influence over the spatial distribution of nutrients, which can reciprocally affect other ecological processes.

The interplay between bedrock topography and soil deposition across the Everglades forms a fine-scale surface mosaic providing a template for hydrologic dynamics. Variation in the depth and period of flooding exists at all scales within the system, and interacts with processes that dominate each level of organization. Data suggest that at the local scale, soil surface rises that may be associated with bedrock outcrops or accumulated dead biomass reduce flooding stress,

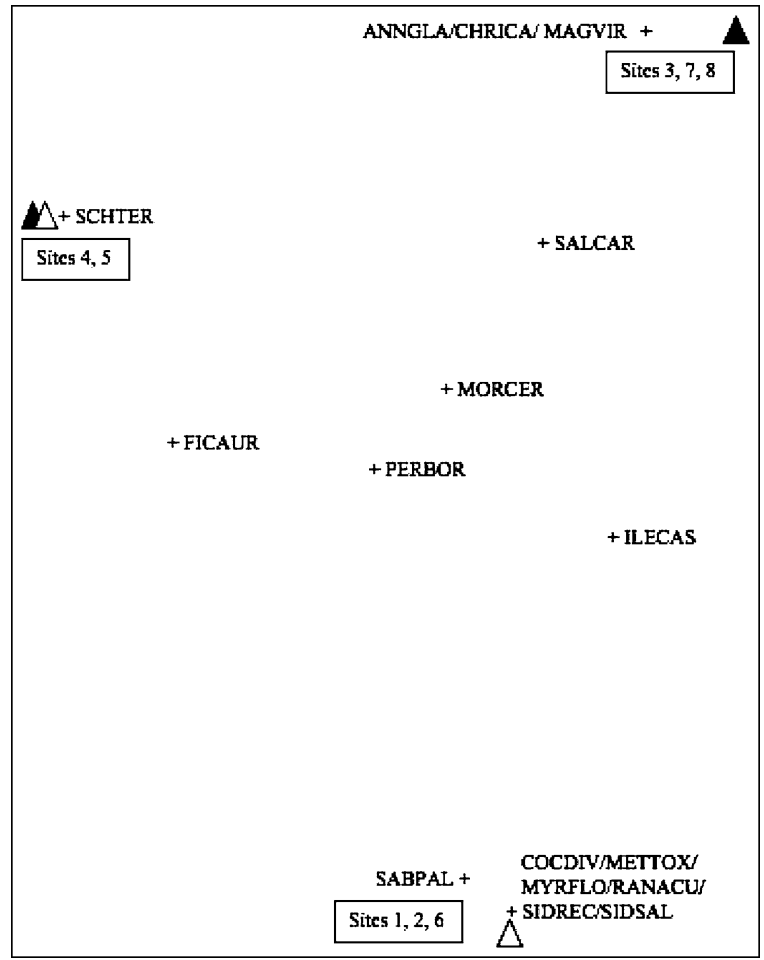

Fig. 4 NMDS site ordination. Species codes represent the first 3 letters of the genus and species names. For complete names see Table 2

thereby enabling woody plant establishment and subsequent nucleation processes. Larger-scale topographic variation exists between the Marl Prairie and Ridge and Slough landscapes, producing considerably longer hydroperiods within the slough than in the prairie. The effects of this contrast are evident in the presence of larger and more developed tree islands within the slough, and the pronounced directional orientation of its landscape features (Ruiz and Ross 2004). Hydrologic differences between the Marl Prairie and Ridge and Slough are also reflected in the sloughs' higher biomass levels, producing thicker more organic soils with drastically lower bulk densities. System-scale hydrologic management further affects the quality, timing and distribution of flooding across landscapes, thereby altering the scale of heterogeneity at lower hierarchical levels.

At the local level, dominant biogeochemical processes appear to be driven primarily by resident biota. For example, TP was significantly more concentrated within tree island soils ubiquitously across our study sites, often by an order of magnitude. 
Fig. 5 Overview of environmental and soil property patterning at different scales

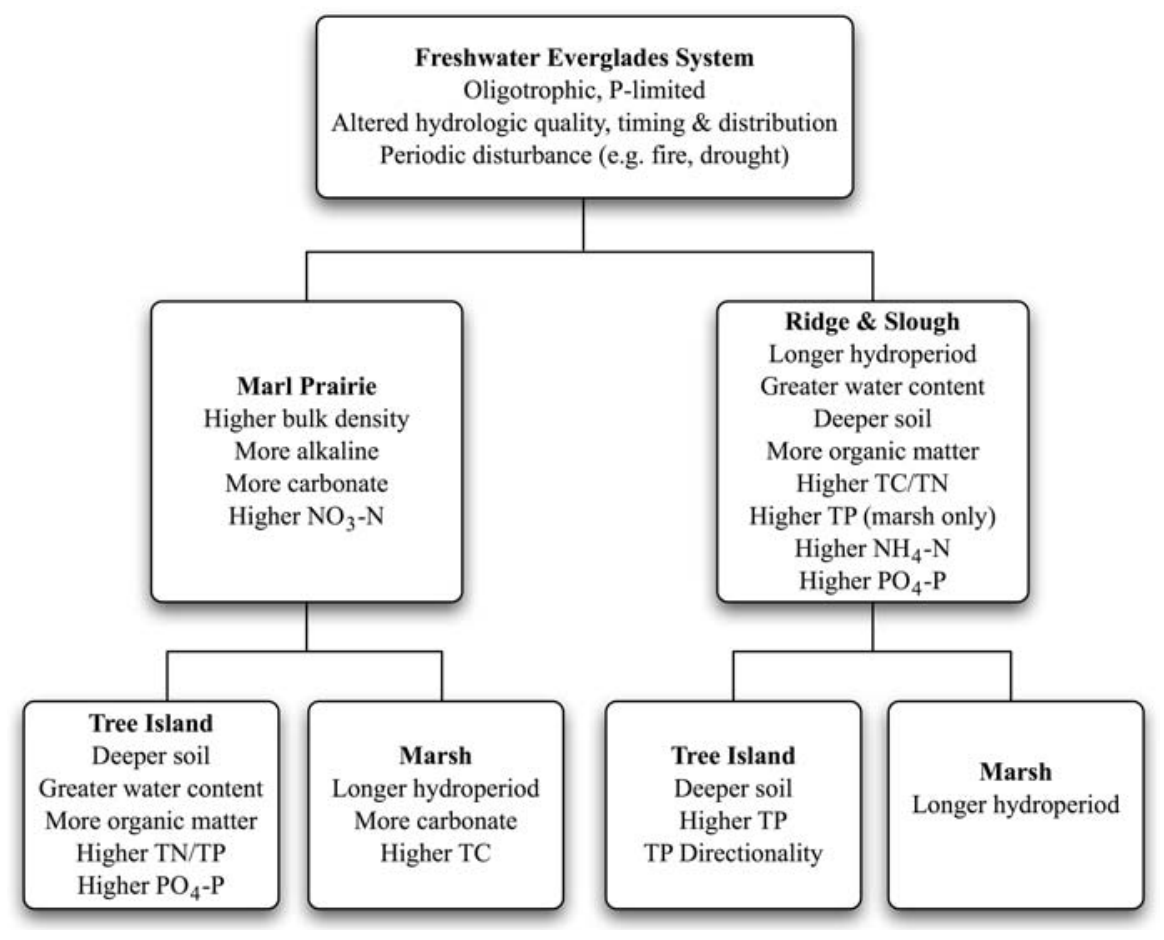

Wetzel et al. (2005) suggested that high tree island TP concentrations are primarily caused by a combination of (1) transpiration driven mass flow of nutrients, (2) use by animals and (3) possible bedrock mineralization by tree exudates. These assumptions were based in part on data collected by Jayachandran et al. (2004), which cited nighttime increases in tree island groundwater levels as evidence for net diurnal groundwater movement from surrounding marshes (i.e. mass flow). They also suggested that $\mathrm{P}$ accumulation might be a byproduct of peat redistribution and subsequent $\mathrm{OM}$ decomposition. As accumulated peat decomposes, $\mathrm{C}$ and $\mathrm{N}$ are cycled into their gaseous phases. Because $\mathrm{P}$ does not have a significant gaseous phase, it may accumulate and be retained in tree island soils. P may also adsorb onto soil particles as calcium phosphate under alkaline conditions.

For tree island nucleation to occur, a portion of accumulated $\mathrm{P}$ must be available for new recruits (Givnish et al. 2008). P-availability and mobility within the Everglades system are primarily controlled by calcium solubility and organic $\mathrm{P}$ metabolism/ mineralization (Reddy et al. 1998), both of which are decelerated by prolonged flooding and alkaline $\mathrm{pH}$. As a result, most Everglades $\mathrm{P}$ exists in biologically unavailable pools, immobilized to a large degree by periphyton (Noe et al. 2001). The significant $\mathrm{PO}_{4}-\mathrm{P}$ gradient found between tree islands and adjacent marshes in the Marl Prairie may result from (1) a greater periphyton contribution in Marl Prairie marshes compared with slough marshes, and (2) the fact that organic tree island soils in the Marl Prairie support more active microbial activity than adjacent mineral soils (Fitter and Hay 2002). Slough sites by contrast exhibit more uniform $\mathrm{OM}$ patterning, and deeper water, thus limiting periphyton productivity. As a result, $\mathrm{PO}_{4}-\mathrm{P}$ levels are consistently low across the Ridge and Slough landscape. However, in both landscapes $\mathrm{PO}_{4}-\mathrm{P}$ present in low concentrations may contribute to tree island nucleation. In conjunction with hydrologic dynamics, localized biological processes such as $\mathrm{P}$ redistribution ultimately give rise to the characteristic tree island-marsh mosaic that exists across both landscapes within the freshwater Everglades system.

Although similar biological processes appear to promote tree island development within the Marl Prairie and Ridge and Slough, system-scale constraints, particularly those relating to hydrology, create some degree of biogeochemical variability between landscapes. For example, TC and TN concentrations were found to correlate with $\mathrm{OM}$ 
accumulation, which was extremely high in the slough relative to the Marl Prairie. OM accumulation within the slough results from (1) higher overall biomass levels, and (2) long hydroperiods that inhibit oxidation and subsidence (Kushlan 1990). Bioavailable $\mathrm{N}$ forms were also most strongly influenced by hydrologic/oxidative conditions, with $\mathrm{NO}_{3}-\mathrm{N}$ accumulating in the shorter-hydroperiod Marl Prairies, and $\mathrm{NH}_{4}-\mathrm{N}$ accumulating in the more anoxic Ridge and Slough (see Fig. 3a).

Wax myrtle (Morella cerifera), a resident $\mathrm{N}$-fixing actinorhizal tree, can complicate $\mathrm{N}$-dynamics at multiple scales. $\mathrm{N}$-fixing symbionts typically have high $\mathrm{P}$ requirements because $\mathrm{N}$-fixation requires a high input of energy (Vitousek and Field 1999). It therefore seems likely that resource islands in the Everglades would be particularly conducive to $\mathrm{N}$-fixation. Although M. cerifera was the dominant woody species across our study sites, tree islands in both prairie and slough were not associated with increased $\mathrm{N}$-availability. These findings may in part result from the fact that the root nodule activity of M. cerifera is significantly reduced during winter months (Permar and Fisher 1983), the time in which our samples were collected. We suspect that under the right conditions $\mathrm{P}$ accumulated within tree islands can enhance local N-supplies, at least in the short term, by promoting the establishment and nodule development of $\mathrm{N}$-fixing species. Because of its influence on vegetation and organic matter dynamics, hydrology is likely the primary driver of N-dynamics across Everglades landscapes.

Sah (2004) found that hydrology also exerted the strongest influence over species composition within Shark Slough tree islands. Similarly, we found that tree island species composition varied significantly between our two hydrologically defined landscapes. Our NMDS ordination grouped Marl Prairie and slough sampling sites into two distinct clusters at either edge of the ordination space, while one site from each landscape comprised a third group. Sites in the third group both exhibited species compositions that differed somewhat from those characteristic to either landscape. Prairie site 5 in particular had high cover by Brazilian pepper (Schinus terebinthifolius), an invasive exotic species. Because nutrient availability significantly constrains plant growth and landscape patterning within terrestrial systems (Lambers et al. 1998), landscape-scale biogeochemical patterns also must play a role in the distinct compositional differences that exist between Marl Prairie and slough tree islands. Recent research supports the assumption that $\mathrm{N}$ and $\mathrm{P}$ resource islands play a sink/source role in landscape-scale biogeochemical cycling (e.g. Jayachandran et al. 2004; Ross et al. 2006; Wetzel et al. 2005, 2009; Givnish et al. 2008), but the spatial patterns of resource island gradients have not yet been fully described.

Large landscape features within Shark Slough and WCAs appear to be oriented and elongated in an approximate downstream direction (Ruiz and Ross 2004; Sklar et al. 2004), and are likely coincident with soil resource directional drift. Directional TP elongation confirmed by our orthogonal contrasts indicates $\mathrm{P}$ movement from slough tree islands downstream into adjacent marshes. Increased downstream $\mathrm{P}$ concentration over time may promote disproportionate expansion, eventually leading to large teardrop-shaped tree islands like those observed within Shark Slough. By contrast, areas of impoundment in WCA-1 (Loxahatchee) contain small tree islands that display almost no vegetational directionality, presumably from lack of flow (Brandt et al. 2002). Similarly, our resource islands within the short hydroperiod Marl Prairie displayed no differences in their upstream vs. downstream TP gradients. While our analysis confirms some TP directionality within the slough, we are confident that further study would reveal a downstream trend concomitant with local tree island patterning. Such spatial analyses may provide a better understanding of both local-scale edge effects, and subsequent landscape-scale dynamics.

According to HPDP, the mechanistic understanding of conditions at a given hierarchical level (e.g. Everglades landscapes) comes from evaluating interactions at the next lower level (e.g. component tree island and marsh patches), while the processes constraining those conditions must be perceived at the next higher level (e.g. freshwater Everglades system; Wu 1999). Interpreting our study analogously, it appears likely that Marl Prairie and Ridge and Slough landscape mosaics emerge primarily via nutrient redistribution and peat accumulation processes occurring at the local scale. Tree island-marsh mosaics are in turn shaped by system-scale hydrologic variability, which affects the size of component patches and influences their directional orientation. 
Related mechanisms have been suggested as the drivers of woody plant patterning across many other landscapes around the globe (e.g. Swanson and Grigal 1988; McCarthy et al. 1993; McCarthy et al. 1998; Rietkerk et al. 2004).

In his synthesis of literature describing tree islands worldwide, Wetzel (2002) classified three major tree island types based on their shape; elongate, round and linear. Elongated tree islands such as those found within the Everglades Ridge and Slough landscape, are consistently aligned parallel to the predominant direction of surface flow. Round or oval-shaped tree islands, such as those found within Marl Prairies tend to exist in wetlands with little or no surface water movement. String shaped tree islands, which do not exist in the Everglades, are aligned perpendicular to the predominant direction of hydrologic flow, forming a step pattern. Most theories suggest that these tree island types emerge via similar biological and environmental feedback processes. For example, McCarthy et al. (1998) reasoned that tree islands in the Okavango delta of Botswana emerge via nucleation around topographic rises associated with termite mounds. Once established, they increase local transpiration thus altering below-canopy soil chemistry and enabling woody patch expansion. Similarly, Rietkerk et al. (2004) found that linear vascular plant patches in northern latitudinal bogs develop through combined organic matter accumulation and nutrient redistribution mechanisms. Such landscapes might also be understood in the context of hierarchy theory; similar local scale processes among systems give rise to tree islands amidst a grassland or herbaceous matrix, while system scale constraints such as hydrologic variability shape tree island patches differently, causing unique landscape patterns to emerge.

\section{Conclusion}

Levels in complex hierarchical systems such as the Everglades are characterized by differing process rates and intensities. Interacting holons at lower tiers are subject to rapid low-intensity processes, whereas slower, more-intense processes occur within higher tiers (Farina 2006). For example, local scale nutrient supplies are prone to rapid change via mass flow, decomposition, etc., which collectively over time generate landscape-scale resource heterogeneity.
Resource islands that gradually form across landscapes may consequently impose a more-long term framework on lower-level redistribution processes. Landscape level holons are themselves constrained by very gradual system-scale processes such as longterm hydrologic flow patterns. Thus, multi-scale analysis is necessary to better understand the complex interactions between hierarchical levels and their component holons within the Everglades system.

Previous studies covering Everglades tree island biogeochemistry typically focused on a single spatial scale, and frequently occurred within the Ridge and Slough landscape (e.g. Orem et al. 2002; Jayachandran et al. 2004; Wetzel et al. 2009). Collectively these studies make a compelling case for autogenic nutrient redistribution associated with large Everglades tree islands. They further suggest that tree islands might play an important $\mathrm{P}$ source/sink role within the larger system. Our multi-scaled sampling approach aimed to better understand how redistribution processes fit into larger-scale Marl Prairie and Ridge and Slough landscape dynamics. Our data suggest that small tree islands found across the entire Everglades system are subject to the same $\mathrm{P}$ accumulation mechanisms as those identified within large Ridge and Slough islands. Moreover, tree island and marsh patches nested within the Marl Prairie and Ridge and Slough landscapes are shaped by disparate hydrologic conditions within the larger system, resulting in two landscapes defined by characteristically different species compositions, patch sizes and downstream resource patterns.

Acknowledgments Many thanks to Krishnaswamy Jayachandran and Jay Sah for discussions that improved our sampling design and analyses; Pablo Ruiz, Rafael Travieso, David Jones, Beyte Barrios, Susanna Stofella and Mike Kline for field assistance; and Len Scinto and Diana Johnson for laboratory instruments and instruction. This work was supported by the Christina Menendez Fellowship awarded by the Miccosukee Tribe of Indians, and enhanced by collaborations with the FCE LTER (funded by NSF, \#DBI-0620409 and \#DEB-9910514). This is SERC Contribution \# 459.

\section{References}

Baker TT, Lockaby BG, Conner WH, Meier CE, Stanturf JA, Burke M (2001) Leaf litter decomposition and nutrient dynamics in four southern forested floodplain communities. Soil Sci Soc Am J 65:1334-1347 
Brandt LA, Silveira JE, Kitchens WM (2002) Tree islands of the Arthur R. Marshall Loxahatchee National Wildlife Refuge. In: Sklar FH, van der Valk A (eds) Tree islands of the everglades. Kluwer, Dordrecht, pp 311-336

Bray JR, Curtis JT (1957) An ordination of the upland forest communities of Southern Wisconsin. Ecol Monogr 27:325-349

Burke IC, Lauenroth WK, Vinton MA et al (1998) Plant-soil interactions in temperate grasslands. Biogeochemistry 42:121-143

Casper BB, Jackson RB (1997) Plant competition underground. Annu Rev Ecol Syst 28:545-570

Dean WE Jr (1974) Determination of carbonate and organic matter in calcareous sediments and sedimentary rocks by Loss on Ignition: Comparison with other methods. J Sediment Petrol 44(1):242-248

EDEN Everglades Depth Estimation Network (2008) South Florida Information Access (Sofia) http://sofia.usgs.gov/ eden. Cited 12. May 2008

Farina A (2006) Principles and methods in landscape ecology. Chapman \& Hall, London

Fitter AH, Hay RKM (2002) Environmental physiology of plants. Academic Press, London

Forester JC (1995) Soil Nitrogen. In: Kassem A, Nannipieri P (eds) Methods in applied soil microbiology and biochemistry. Academic Press, CA, pp 79-87

Gillson L (2004) Evidence of hierarchical patch dynamics in an East African Savanna? Landscape Ecol 19:883-894

Givnish TJ, Volin JC, Owen VD, Volin VC, Muss JD, Glaser $\mathrm{PH}$ (2008) Vegetation differentiation in the patterned landscape of the central Everglades: Importance of local and landscape drivers. Glob Ecol Biogeogr 17(3):384-402

Gunderson LH (1994) Vegetation of the everglades: Determinants of community composition. In: Davis SM, Ogden JC (eds) Everglades: The ecosystem and its restoration. St. Lucie Press, Boca Raton, pp 323-340

Harris W, Hurt W (1999) Introduction to soils of subtropical Florida. In: Reddy K, O'Connor G, Schelske C (eds) Phosphorus biogeochemistry in subtropical ecosystems. Lewis, Boca Raton, pp 143-167

Hofmockel K, Richardson CJ, Halpin PN (2008) Effects of hydrologic management decisions on everglades tree Islands. In: Richardson CJ (ed) The everglades experiments: Lessons for ecosystem restoration. Springer, New York, pp 191-214

Jayachandran K, Sah SK, Sah JP, Ross MS (2004) Characterization, biogeochemistry, pore water nutrient chemistry, and other aspects of soils in tree islands of shark slough. In: Ross MS, Jones DT (eds) Tree islands in the shark slough landscape: interactions of vegetation, hydrology and soils. Report submitted to Everglades National Park, pp 45-82

Jones BJ Jr (2001) Laboratory guide for conducting soil tests and plant analysis. CRC Press, Boca Raton, pp 27-41 \& 152-154

Kadlec RH (1999) Transport of Phosphorus in Wetlands. Introduction to soils of Subtropical Florida. In: Reddy K, O'Connor G, Schelske C (eds) Phosphorus biogeochemistry in subtropical ecosystems. Lewis, Boca Raton, pp 355-375
Kruskal JB (1964) Multidimensional scaling by optimizing goodness of fit to a nonmetric hypothesis. Psychometrika 29:1-27

Kushlan JA (1990) Freshwater marshes. In: Myers RL, Ewel JJ (eds) Ecosystems of Florida. University of Central Florida Press, Orlando, pp 324-363

Lambers H, Chapin FS III, Pons TL (1998) Plant physiological ecology. Springer Science, Inc, New York

Loveless CM (1959) A study of the vegetation in the Florida everglades. Ecology 40:1-9

Lynn WC, McKenzie WE, Grossman RB (1974) Field laboratory tests for characterization of Histosols. In: Stelly M (ed) Histosols: their characteristics, classification and use. SSSA Spec. Pub. 6, Madison, pp 11-ss20

Mather PM (1976) Computational methods of multivariate analysis in physical geography. Wiley, London

McCarthy TS, Ellery WN, Ellery K (1993) Vegetation-induced, subsurface precipitation of carbonate as an aggradational process in the permanent swamps of the Okavango (delta) fan, Botswana. Chem Geol 107:111-131

McCarthy TS, Ellery WN, Dangerfield JM (1998) The role of biota in the initiation and growth of islands on the floodplain of the Okavango alluvial fan, Botswana. Earth Surf Process Landforms 23:291-316

McGrath DA, Smith CK, Gholz HL, de Assis Oliveira F (2001) Effects of land-use change on soil nutrient dynamics in amazônia. Ecosystems 4:625-645

Mehlich A (1972) Uniformity of expressing soil test results: a case for calculating results on a volume basis. Commun Soil Sci Plant Anal 3:417-424

Miller JR, Turner MG, Smithwick EAH, Dent CL, Stanley EH (2004) Spatial extrapolation: the science of predicting ecological patterns and processes. Bioscience 54(4): 310-320

Mulvaney RL (1996) Nitrogen-inorganic forms. In: Sparks DL (ed) Methods of soil analysis. SSSA Book Ser. 5. SSSA, Madison, pp 1123-1184

Noe GB, Childers DL, Jones RD (2001) Phosphorus biogeochemistry and the impact of phosphorus enrichment: why is the everglades so unique? Ecosystems 4:603-624

O'Dell JW (1993) Determination of phosphorus by semiautomated colorimetry. Environmental monitoring systems laboratory office of research and development US. Environmental Protection Agency Cincinnati, Ohio

Olsen SR, Cole CL, Watanabe PS, Dean LA (1954) Estimation of available phosphorus in soils by extraction with sodium bicarbonate. USDA Circ 939

Orem WH, Willard DA, Lerch HE, Bates AL, Boylen A, Comm M (2002) Nutrient geochemistry of sediments from two tree islands in Water Conservation Area 3B, the Everglades, Florida. In: Sklar FH, van der Valk A (eds) Tree islands of the everglades. Kluwer, Dordrecht, pp 153-186

Patterson K, Finck R (1999) Tree islands of the WCA-3 aerial photointerpretation and trend analysis project summary report. St Petersburg, FL: South Florida Water Management District. Report to the South Florida Water Management District by Geonex Corporation

Permar TA, Fisher RF (1983) Nitrogen fixation and accretion by wax myrtle (Myrica cerifera) in slash pine (Pinus elliottii) plantations. For Ecol manage 5(1):39-46 
Reddy KR, Wang Y, DeBusk WF, Fisher MM, Newman S (1998) Forms of soil phosphorus in selected hydrologic units of the Florida Everglades. Soil Sci Soc Am J 62:1134-1147

Rietkerk M, Dekker SC, Wassen MJ, Verkroost AWM, Bierkens MFP (2004) A putative mechanism for bog patterning. Am Nat 163:699-708

Ross MS, Mitchell-Bruker S, Sah JP et al (2006) Interaction of hydrology and nutrient limitation in the Ridge and Slough landscape of the southern Everglades. Hydrobiologia 569:37-59

Ruiz PL, Ross MS (2004) Vegetation mapping and landscape pattern in shark slough. In: Ross MS, Jones DT (eds) Tree islands in the shark slough landscape: interactions of vegetation, hydrology and soils. Report submitted to Everglades National Park, pp 45-82

Sah JP (2004) Vegetation structure and composition in relation to hydrological and soil environments in tree islands of shark slough. In: Ross MS, Jones DT (eds) Tree islands in the shark slough landscape: interactions of vegetation, hydrology and soils. Report submitted to Everglades National Park, pp 85-112

Schlesinger WH, Raikes JA, Hartley AE, Cross AF (1996) On the spatial patterns of soil nutrients in desert ecosystems. Ecology 77:364-374

Sklar FH, Coronado C, Crozier G et al. (2004) Everglades consolidation report, Chapter 6: Ecological effects of hydrology. South Florida Water Management District, West Palm Beach, FL, USA

Solorzano L, Sharp JH (1980) Determination of total dissolved phosphorus and particulate phosphorus in natural waters. Limnol Oceanogr 25(4):754-758
Swanson DK, Grigal DF (1988) A simulation model of mire patterning. Oikos 53:309-314

Vitousek PM, Field CB (1999) Ecosystem constraints to symbiotic nitrogen fixers: a simple model and its implications. Biogeochemistry 46:172-202

Vitousek PM, Sanford RL Jr (1986) Nutrient cycling in moist tropical forest. Annu Rev Ecol Syst 17:137-167

Watt AS (1947) Pattern and process in the plant community. J Ecol 35:1-22

Wetzel PR (2002) Tree islands around the world. In: Sklar FH, van der Valk A (eds) Tree islands of the everglades. Kluwer, Dordrecht, pp 19-70

Wetzel PR, Van der Valk AG, Newman S et al (2005) Maintaining tree islands in the Florida Everglades: nutrient redistribution is the key. Front Ecol Environ 3(7):370-376

Wetzel PR, van der Valk AG, Newman S et al (2009) Phosphorus concentration in a patterned landscape, the Florida everglades. Plant Ecol 200:83-90

White PS (1994) Synthesis: vegetation pattern and process in the everglades ecosystem. In: Davis SM, Ogden JC (eds) Everglades: the ecosystem and its restoration. St. Lucie Press, Boca Raton, pp 445-460

Wu J (1999) Hierarchy and scaling: extrapolating information along a scaling ladder. Can J Remote Sens 25:367-380

Wu J, Loucks OL (1995) From balance-of-nature to hierarchical patch dynamics: a paradigm shift in ecology. Q Rev Biol 70:439-466 